\section{LEGUMES' CONTRIBUTIONS TO GENETIC RESEARCH, A HISTORICAL PERSPECTIVE FROM MENDELISM UP TO MASSIVE SEQUENCING}

\author{
Marcelino Pérez de la Vega \\ Universidad de León \\ m.perez.delavega@unileon.es
}

\section{CONTRIBUCIÓN DE LAS LEGUMINOSAS A LA INVESTIGACIÓN GENÉTICA, UNA PERSPECTIVA HISTÓRICA DESDE LA GENÉTICA MENDELIANA A LA SECUENCIACIÓN MASIVA}

Cómo citar este artículo/Citation: Pérez de la Vega, M. (2016). Legumes' contributions to genetic research, a historical perspective from Mendelism up to massive sequencing. Arbor, 192 (779): a318. doi: http://dx.doi.org/10.3989/ arbor.2016.779n3008

Recibido: 08 marzo 2016. Aceptado: 06 mayo 2016.

ABSTRACT: It is well known that Mendel chose peas as the study material for his experiments that are the cornerstone of genetics. Nonetheless, it is less known that he also experimented with other legumes although with reduced success, or that Darwin also experimented with legumes. During the first decade of the twentieth century, peas were the favorite material used to verify Mendel's results. Although genetics after that time primarily developed using other eukaryotic organisms or microorganisms, legumes pertain to the core material that allowed Vavilov to develop his Law of Homologous Series in Variation. They have also been used as a model to study plant-microbe symbiotic relationships that enable the fixation of atmospheric nitrogen, making them one of the biological models of the genomic age. Over the last five years, several genome sequences of cultivated legume species have been published, with many more to be made public in the upcoming years. Consequently, the amount of theoretical knowledge accumulating in this area and its application in plant breeding are increasing exponentially.

KEYWORDS: legumes; peas; Mendel; Darwin; Vavilov.
Copyright: ( 2016 CSIC. Este es un artículo de acceso abierto distribuido bajo los términos de la licencia Creative Commons Attribution (CC BY) España 3.0.
RESUMEN: Es conocido que Mendel escogió los guisantes como material para realizar los experimentos que son la piedra fundacional de la Genética. Pero es menos conocido que Mendel también experimentó con otras leguminosas con menos éxito, o que Darwin experimentó con leguminosas. Durante la primera década del siglo $\mathrm{XX}$, los guisantes fueron el material predilecto para comprobar los resultados obtenidos por Mendel. Después, la Genética se desarrolló utilizando prioritariamente otros organismos eucariotas o microorganismos. Aun así, las leguminosas forman parte de los materiales en los que Vavilov se basó para desarroIlar su Ley de las Series Homólogas en la Variación. Las leguminosas son el modelo para el estudio de las relaciones simbióticas planta-microorganismo que posibilitan la fijación de nitrógeno atmosférico. Esto las ha convertido en uno de los modelos biológicos en la era de la genómica. En el último lustro se ha terminado la secuenciación de varios genomas de especies cultivadas de leguminosas y muchos otros lo serán en los próximos años. Como consecuencia de ello la cantidad de conocimientos teóricos y su aplicación a la mejora está aumentando exponencialmente.

PALABRAS CLAVE: leguminosas; guisantes; Mendel; Darwin; Vavilov. 
Cold-season legumes, along with wheat and barley, are part of the first group of plant species domesticated 10,000-11,000 years ago in the Fertile Crescent, setting the foundation on which the origin of agricultural societies was based in this region. From the Fertile Crescent, the already domesticated peas, lentils, faba beans, etc., gradually spread to other regions, so they were well known in the Classical period of Western Culture. The origins of agriculture in others areas are also linked to legume domestication such as common bean in America or soya bean in the Far East. In the scientific world, peas are known to be the biological material used in Mendel's "hybridization" experiments eventually representing the cornerstone of Genetics. But why did he use peas instead of any other material?

If we go back to the historical background of Genetics, we can see that Mendel's work results from the nineteenth century widespread concern regarding the existence of sexual reproduction in plants, and the mutable or else immutable nature of species, which in turn was related to the controversy over whether it was possible to produce new species through the hybridization between species. The protogenetic investigations were based on observing changes of easily discernable characters in two types of hybrids (Jahn, Lother and Senglaub, 1990):

1. Hybrids from cultivated species, with an eminently practical importance in agriculture and gardening.

2. "Natural" hybrids, led to the attempt to explain questions about the limits and transformations of the species with taxonomic purposes.

Therefore, hybridization experiments (including both cross hybridization between different species and intraspecific crosses, as Mendel performed) in the nineteenth century responded to a double concern. The theoretical analysis of the species concept and the species' levels of variability, next to the concern of obtaining useful and stable novel cultivated forms.

A reflection of the great interest that existed in the nineteenth century with respect to experimentation with hybrids can be appreciated by the great number of contests summoned by the various scientific academies. For example, the Royal Prussian Academy of Sciences in 1819 and 1828 (Does hybrid fertilization occur in the Plant Kingdom?); the Royal Netherlands Academy of Sciences in 1830 Haarlem (What does experience teach regarding the production of new species and varieties, through the artificial fertilization of flowers of the one with the pollen of the others, and what economic and ornamental plants can be produced and multiplied in this way?), or the Faculty of Philosophy at the University of Munich in 1834 on the definition and variability of species (Roberts, 1919; Jahn et al., 1990). Yet experiments involving plant hybridization can be traced back to 1694 undertaken by Rudolf Jacob Camerarius or Camerer (1666-1721), director of the Botanical Garden of Tübingen and author of "De sexu plantarum epistola" (1694), thereafter continued by Joseph Gottlieb Kölreuter (1733-1806) and Carl Friedrich von Gärtner (1772-1850) (Smykal, 2014). It is not surprising therefore that in a scientific environment in which hybridization, the fixation or variation of species' characters, the sterility of certain hybrid plant forms, the "dilution" of hybrid characters in subsequent generations, the possibility to obtain new species by hybridization, etc., were all subject of intense discussions and the underlying framework supporting Mendel's work.

The first study to assess variation in pea, and the transmission of some characteristics from one generation to the next, was carried out by Thomas Andrew Knight (1759-1838) who, although more interested in fruit trees realized that it was better to develop this kind of studies with annual species, such as pea, instead of perennial species with long life cycles as fruit trees (Smykal, 2014). Some 70 years before Mendel, Knight had studied the inheritance of flower color in pea and his work made some introductory considerations that recall those delivered by Mendel. It is likely that Mendel was familiar with Knight's work and that this influenced the material's choice to work with (Roberts, 1929; Hellens et al., 2010; Smykal, 2014). Knight's paper, read before the Horticultural Society, June 3, 1823 was, in part, a reply to certain experiments by John Goss using the same plant species. A year before, the paper of Goss had been read before the Horticultural Society in which, although Goss undoubtedly had made evident the circumstances of dominance and segregation, he had not recognized them properly as such, or had made counts as had Mendel, determining the number of seeds of the two colors found on each separate plant (Roberts, 1929). The phenomena of dominance and of segregation had also been observed by Alexander Seton, who a few months earlier had read a communication before the Horticultural Society on the same subject, but owing to the fact that the number of the seeds had not been totaled, the results were not suitable for scientific purposes, nor did they arouse attention, any more than had those of Goss, except for the further work carried out by Mendel (Roberts, 1929). According to Roberts (1929), the last pea hybridization 
experiments undertaken before the final rediscovery of Mendel's work were published by Thomas Laxton in the Journal of the Royal Horticultural Society (1872). In the paper, entitled "Notes on Some Changes and Variations in the Offspring of Cross-fertilized Peas", some points of interest were issued: "dominance" in color and form of the seeds was pointed out, and to a certain limited extent, a numerical analysis of the results was attempted.

In this scientific context Mendel $(1822-1884)$ carried out his experiments first read at the meetings taking place the $8^{\text {th }}$ of February and $8^{\text {th }}$ of March, in the year 1865, at the Natural Science Association in Brno, being published the following year in the Association's Proceedings (Mendel, 1866). The paper entitled "Versuche über Pflanzen-Hybriden", and known in English as Experiments in Plant Hybridization, although a more proper translation would be Experiments in Plant Hybrids (Ellis, Hofer, Timmerman-Vaughan, Coyne and Hellens, 2011), accurately describes the procedure followed and the results obtained: the principles of segregation and independent assortment, as well as the effect of dominance. The best known version of Mendel's paper is the translation to English completed by Bateson in 1909 and printed out in other reviews such as the one by Franklin, Edwards, Fairbanks, Hartl and Seidenfrld (2008).

Another important historical issue is the question why the work of Mendel did not influence Darwin's thinking. There is no evidence that Darwin had ever read Mendel's paper, although proof exists that Mendel was acquainted with 'On the Origin of Species'. According to Galton (2009), Mendel had read and studied the German translation, as soon as the second edition was printed in 1863 , and he wrote many notes along the margin and underlined some of the text. Furthermore, he bought most of Darwin's other works and studied them. Mendel ordered 40 reprints of his paper to be sent to scientists and Institutions, nevertheless no evidence exists that Darwin read Mendel's paper or any other further study referring to the Mendel's work. Galton (2009) reveals that probably the mathematical form used by Mendel to present his results might have put Darwin off from reading any more of the article. Darwin once said that: "Mathematics in Biology was like a scalpel in a carpenter's shop, there was no use for it". Another important difference entails the different approaches used for the analysis of the biological inheritance by Mendel and the biological evolution by Darwin. Mendel placed the focus on qualitative characters while Darwin focused on quantitative variation. Darwin's focus on small quantitative variations as the raw material of evolution may have prevented him from discovering the laws of inheritance (Howard, 2009).

It is therefore not surprising that in a scientific environment in which these topics (evolution, hybridization and inheritance) were hotly discussed, being the number of related publications very large for the period, the results of Mendel's work went unnoticed. The literature on hybrids over the next 20 years after the appearance of Darwin's 'On the Origin of Species' (1859) was so numerous that hardly anyone interested in hybridization experiments would have been able to review all of it (Jahn et al., 1990). The reason for this subject's sudden boost was due to the publication of Darwin's work, which strengthened the discussion on the concept of species, together with their immutability or not, thus making even more interesting the hybridization experiments from a theoretical point of view.

Darwin's natural selection is one of the milestones in the history of science but its weakest point was precisely that there was no heredity theory that suited the nineteenth century evolutionary theory. Soft inheritance and blending inheritance were the predominant hypotheses regarding biological inheritance in the XIX century. Soft inheritance, a term coined by Mayr, refers to the now disaccredited "Lamarckian" idea that characteristics acquired during a lifetime can be passed on to the offspring (not to be confused with epigenetics). Blending inheritance refers to the idea that the inherited traits were the result of a random admixture of the homologous traits found in the parents. In this regards it is interesting to include a few paragraphs derived from the book of Mayr (1982) in relation to Darwin's work. "Inheritance implies continuity and constancy; variation implies change and divergence. When breeder crossed animals or plants, he often encountered unexpected variants among the offspring"... "Eventually it became an important question. Where does the new variation come from? But it was not until Darwin had established his theory of natural selection that the source of variation became a key problem in biology. Natural selection can be effective only if there is an abundant supply of variation, a supply that must be forever renewable. How can this fact be reconciled with a belief in the constancy of inheritance?" Later Mayr continues: "It is one of the great ironies in the history of science that the answer to the problem of heredity had already been found while so many distinguished investigators searched for it so assiduously during the 1870 s, 80 s and 90 s". $^{\prime \prime}$ 
If almost nobody had paid due attention to Mendel's work, this is particularly inexcusable in the case of Nägeli (Professor of Botany at several universities, Freiburg, Munich and Zurich) with whom Mendel had maintained an intense scientific correspondence. Also Focke uncovered the work of Mendel to the rest of the scientific community. This researcher reviewed the scientific literature produced by "breeders" and "hybridizers" and published in 1881 a book entitled "Plant Hybrids" (Die Pflanzen-Mischlinge), which included a compilation of data on the subject, including results of Mendel, although paradoxically Focke's review briefly mentioned Mendel's Phaseolus and Hieracium hybridizations, inconsequential today, not sufficiently highlighting the pea results (Stern and Sherwood, 1966).

Returning to Darwin's contribution to Science, it is noteworthy to mention that legumes were also among the many plant and animal species that he used in his experiments. He analyzed the effect of cross-pollination vs. self-pollination in pea, describing what nowadays is known as hybrid vigor or heterosis (Darwin, 1876). "The common pea is perfectly fertile when its flowers are protected from the visits of insects; I ascertained this with two or three different varieties, as did Dr. Ogle with another. But the flowers are likewise adapted for cross-fertilisation". Then, he continues to describe the uniformity of the self-fertilized (homozygous) peas: "Notwithstanding these manifest provisions for cross-fertilisation, varieties which have been cultivated for very many successive generations in close proximity, although flowering at the same time, remain pure". And he continues. "Owing to the varieties having been self-fertilised for many generations, and to their having been subjected in each generation to nearly the same conditions (as will be explained in a future chapter) I did not expect that a cross between two such plants [from the same variety] would benefit the offspring; and so it proved on trial"...."There can be no doubt that the result would have been widely different, if any two varieties out of the numberless ones which exist had been crossed. Notwithstanding that both had been self-fertilised for many previous generations, each would almost certainly have possessed its own peculiar constitution; and this degree of differentiation would have been sufficient to make a cross highly beneficial". Here Darwin refers to the experiments undertaken by Knight and by Laxton and continued "A similar trial was subsequently made with two other peas from a different cross, and the result was nearly the same. For instance, a crossed seedling between the Maple and Purple-podded pea was planted in poor soil and grew to the extraordi- nary height of 116 inches; whereas the tallest plant of either parent variety, namely, a Purple-podded pea, was only 70 inches in height; or as 100 to 60 [pages 160 to 163]". In a different chapter Darwin insisted on the same idea. "On the other hand, a cross between two varieties of the pea causes a marked superiority in the growth and vigour of the offspring, over the self-fertilised plants of the same varieties, as shown by two excellent observers. From my own [page 264]". It is also interesting to read a summary of the research carried out by Darwin with legumes: "Summary on the Leguminosae.-Six genera in this family were experimented on, and the results are in some respects remarkable. The crossed plants of the two species of Lupinus were conspicuously superior to the self-fertilised plants in height and fertility; and when grown under very unfavourable conditions, in vigour. The scarlet-runner (Phaseolus multiflorus) is partially sterile if the visits of bees are prevented, and there is reason to believe that varieties growing near one another intercross. The five crossed plants, however, exceeded in height the five self-fertilised only by a little. Phaseolus vulgaris is perfectly self-sterile; nevertheless, varieties growing in the same garden sometimes intercross largely. The varieties of Lathyrus odoratus, on the other hand, appear never to intercross in this country; and though the flowers are not often visited by efficient insects, I cannot account for this fact, more especially as the varieties are believed to intercross in North Italy. Plants raised from a cross between two varieties, differing only in the colour of their flowers, grew much taller and were under unfavourable conditions more vigorous than the self-fertilised plants; they also transmitted, when self-fertilised, their superiority to their offspring. The many varieties of the common Pea (Pisum sativum), though growing in close proximity, very seldom intercross; and this seems due to the rarity in this country of the visits of bees sufficiently powerful to effect cross-fertilisation. A cross between the self-fertilised individuals of the same variety does no good whatever to the offspring; whilst a cross between distinct varieties, though closely allied, does great good, of which we have excellent evidence [pages 168-169]" (Darwin, 1876).

Well known is the simultaneous "rediscovery" of Mendel's Laws in the year 1900 independently by three researchers, Hugo de Vries (1848-1935), Carl Correns (1964-1933) and Erich von Tschermak (18711962). Among the three original works, peas are not mentioned in the paper of de Vries; although he mentions several interspecific hybrids between pairs of different plant species and he highlights an almost 
perfect 3:1 segregation in all cases. The last sentence of his paper reads: "The totality of these experiments establishes the law of segregation of hybrids and confirms the principles that I have expressed concerning the specific characters considered as being distinct units". The paper by Correns focused on pea results: "In the following I shall limit myself to an account of the experiments with varieties of peas. Inter-varietal hybrids of maize show identical behavior in all essential points, but are more difficult to experiment with, and I have not yet elucidated to my satisfaction several points of secondary importance". It is interesting to quote one of the ending sentences related to segregation: "At present, however, this law is applicable only to a certain number of cases, i.e. those where one member of a pair of characters is dominant, and probably only to hybrids between varieties. It seems impossible that all pairs of characters of all hybrids should behave according to this law. Some hybrids of peas bear this out". Tschermak starts his classical paper this so: "Stimulated by the experiments of Darwin on the effects of cross and self-fertilization in the plant kingdom, I began, in the year 1898 to make hybridization experiments with Pisum sativum". One of the sentences in this paper would be quite familiar to any student of basic Genetics: "The ratio of seeds carrying the dominant, prevailing character to those carrying the recessive is about $3: 1^{\prime \prime}$

Yet the first major promoter of Mendel's work was William Bateson (1865-1926). Bateson translated Mendel's paper into English for the first time, and wrote a general exposition that laid out the basic principles of what soon became to be known as 'Mendelism' (Allen, 2003). William Bateson, the first historian of Mendel's work stated: "With the year 1900 a new era begins. In the spring of that year there appeared, within a few weeks of each other, the three papers of de Vries, Correns, and Tschermak giving the substance of Mendel's long-forgotten treatise. Each of these three writers was able to from his own experience to confirm Mendel's conclusions, and to extend them to other cases. There could therefore, from the first, be no question as to the truth of the facts.....the original [Mendel's] paper is a model of lucidity and expository skill. His success is due to the clearness with which he thought out the problem" (Bateson, 1909).

In spite of the optimistic sentence by Bateson ".... be no question as to the truth of the facts...", the results of Mendel's experiments were questioned, with peas being part of the arguments against Mendel's laws. For instance, Weldon (1902) expressed: "I think we can only conclude that segregation of seed-characters is not of universal occurrence among cross-bred Peas, and that when it does occur, it may or may not follow Mendel's law. The law of segregation, like the law of dominance, appears therefore to hold only for races of particular ancestry". But the main argument was that the results of the Mendel's experiments were "too good to be true". To put it simply, the veiled accusation by Weldon (1902) and by Fisher (1936) expressed that Mendel might have adjusted the real results of his experiments to the expected ones in accordance to his biological inheritance hypothesis. Thus, peas are also among the most significant alleged examples of scientific fraud. Fisher's paper (Fisher, 1936) reveals his admiration for Mendel's work. Nonetheless, it is also best known for its conclusion, the same as Weldon had suggested 32 years earlier, expressly that Mendel's results were consistently too close to the expected ratios consequently the result's validity needed to be questioned (Fairbanks and Rytting, 2001). Fisher's work spawned a series of papers dealing with this issue (see Fairbanks and Rytting, 2001; Franklin et al., 2008). The two main conclusions contained in the book by Franklin et al. (2008) are the following: 1) Mendel was not guilty of fraud and 2) Fisher's conclusion that Mendel's data fit expectations extraordinarily well was correct, but could be explained without having to invoke fraud.

Shortly after the rediscovery of the Mendel's laws, a further remarkable contribution of peas to science occurred in the field of proteins, allowing for their classification and nutritional value assessment (Osborne and Harris, 1907; Osborne and Heyl, 1908a; Osborne and Heyl, 1908b).

Another pioneering contribution of peas to the field of Genetics embodies one of the first approaches to quantitative trait analysis together with the possible association between morphological traits and the biological cycle duration. Keeble and Pellew (1910) published in the first issue of the Journal of Genetics a study on the size of pea plants, its possible causes (length of internodes and stem diameter) and its relationship with flowering date. They found that some $F_{2}$ plants were taller or shorter than the parental plants, suggesting a transgressive inheritance, yet the analysis adjusted to a 9: 3: 3: 1 segregation. This trait, typically of a quantitative nature, behaved as a qualitative character because it had been analyzed as such, categorically with four classes: high, medium high, medium low and dwarf. They had not evidenced the insight of East $(1910 ; 1916)$ and Nilsson-Ehle (1908 and 1911) who had recognized the continuous variation underlying a trait such as height. 
An additional key, and more important, contribution of legumes to the discipline of Genetics is due to Wilhelm Johannsen (1857-1927). Johansen coined the concepts of genotype and phenotype (Johannsen, 1909). He considered the phenotype as the set of observable properties of an organism produced by the interaction between the genotype (the sum of its genetic information) and the environment in which it finds itself, abbreviated usually represented as $P=G+E$. Using common bean (Phaseolus vulgaris), Johannsen realized that individuals with the same genotype can show different properties such as seed size, and deduced that such observed phenotypic differences must have been caused by the environment. The main difference with other pioneers of Mendelism is that Johannsen used quantitative characters and, even more important, he analyzed them as quantitative (size, weight) observing continuous variations within each genotype which could be explained by environmental effects. Probably, if Keeble and Pellew (1910) had known the results of Johannsen, their work's focus and their conclusions would have been entirely different.

A further significant contribution of legumes to $\mathrm{Bi}$ ology is due to the Law of Homologous Series in Variation (Vavilov, 1922). Vavilov noted that the shape, color of seeds and cotyledons, spot patterns of seeds, and other easily discernable characteristics of seeds and plants, were shared by various legume species or by cereal species, and they were similar or identical among close species. Peas were the first included in the legume species list of Vavilov's comparative study, together with vetch (Vicia sativa L.), fava bean ( . faba L.), lentil (Vavilov used Lens esculenta Moench, a synonymous currently in disuse of $L$. culinaris Medik.), grass pea (Lathyrus sativus L.), chickpea (Cicer arietinum L.), soybean (Glycine hipida Max., probably a misprint of G. hispida (Moench) Max., which nowadays is a disused synonymous of G. $\max$ (L.) Merr.), common bean (Phaseolus vulgaris L.), sword bean (Cannabalia gladiata (Jacq.) DC.), velvet bean (Stizolobium hassjoo Piper, who again is an obsolete synonymous of Mucuna pruriens (L.) DC.), pigeon pea (Cajanus indicus Spreng. syn. Cajanus cajan (L.) Huth.), lucerne (Medicago sativa L.), red clover (Trifolium pratense L.) and bird's-foot trefoil (Lotus corniculatus L.). Vavilov's Law of Homologous Series in Variation may be summarized as follows:

1. Species and genera genetically related are characterized by a similar series of heritable variation with such a regularity that, knowing the series of forms in a species, one can predict the existence of parallel forms in other species and genera. The greater the similarity in the series of variation, accordingly species and genera are genetically closer within the series.

2. Whole families of plants are generally characterized by a well-defined pattern of change in all genera and species of the family.

This law does not only apply to plants, it is as well applicable to all organism groups. Like the color and spot patterns of legume seeds are similar, analogously are also the coat patterns between species of for instance the genus Pantera or other "cat" genera. Ultimately, the law of homologous series indicates that the variation displayed among related species entails similar characteristics (morphological and also molecular) and that the equivalent characters are controlled by homologous genes (orthologs or paralogs). This law is in fact the basis of the comparative genetics and genomics. Almost simultaneously, Sax (1923) proposed a method to locate quantitative trait loci (QTLs) on a linkage map through association of the trait with marker loci, he demonstrated the association of seed size (a quantitative trait) with seed-coat pigmentation (qualitative) in common bean (Phaseolus vulgaris).

After these pioneering contributions of legumes, in particular pea, research in Genetics changed model species. Drosophila and corn (Zea mays) became the main protagonists respectively as animal and plant model species, later on yeasts, bacteria and viruses stormed into the field of genetic experimentation. The principle of the chromosome theory also known as the chromosomal theory of inheritance, the other great pillar of Genetics, was demonstrated using Drosophila and corn as experimental materials. In the first decade of the twentieth century, Thomas Hunt Morgan (1866-1945) introduced Drosophila as the model species par excellence in Genetics. Since then it remains as a reference species in Genetics. Simultaneously, in the United States, maize breeding was in full swing, so in the early twentieth century the basic and applied research carried out in corn had an outstanding development. Between 1910 and 1931 the studies demonstrating the chromosome theory were published; Morgan, Bridges and Stern used Drosophila while Creighton and McClintock used corn.

Although legumes did not play a leading role in the classical period of Genetics, pea remained as a reference. Peas, as garden and orchard plants, also grown in extensive farming and consumed as dry or fresh seeds, as a vegetable, also used for animal feed, had accumulated a large number of variants (mutants) 
even before Mendel. Therefore, in the age of classical genetics, when the only way to recognize the existence of a gene consisted of finding an inherited variant of an observable character, peas were used as a model plant to identify plant genes and their functions.

Queries using the Thomson Reuters database "The Web of Science", returned for the keyword "Pisum" 26,260 items from 1900 up to the present, distributed along several main categories: "Plant Science", 12,495; "Biochemistry and Molecular Biology", 5,776; "Agriculture", 3,451; "Genetics and Heredity", 2,407 (although the same item can be indexed in two or more categories, depending on the magazine in which published). The number yielded rises up to 72,598 if the key word "pea" is added to include studies in many other scientific disciplines such as nutrition or medicine. Curiously, one of the first pea studies recollected in this database is a note "News and Views" published in Science in 1898 (Anonymous, 1898) entitled "Pea-soup as a substitute for beef-tea". The note summarized an article published in the British Medical Journal about the benefits of pea soup. It is interesting to note that, since the late nineteenth century, legumes were considered suitable for patients with intestinal cancer and diabetes: “...emphatically recommends pea-soup as an excellent substitute for beef-tea for invalids, convalescents, and more especially for patients suffering from cancer of the stomach, or diabetes mellitus ......". The statement may appear surprising, but the author reminds us that: “... peas (as well as beans or lentils, either of which may be used instead of peas) contain a considerable portion of legumen; that is, a vegetable albumen which is easily soluble in a faintly alkaline water, is not coagulated by heat, is easily absorbed, and equal to the albumen of eggs in its nutritiousness". The benefits of legumes to prevent intestinal cancer and to maintain blood sugar levels is somewhat vindicated again in the XXI century.

Of course, legumes have contributed to understand the genetic relationships between plants and microorganisms, mainly in relation to the symbiotic-mutualistic relationship with nitrogen-fixing bacteria. The discovery of nitrogen fixation is attributed to the German scientists Hellriegel and Wilfarth, who in 1886 reported that legume root nodules could convert atmospheric nitrogen into ammonia. Two years later in 1888, Beijerinck, a Dutch microbiologist succeeded to isolate a bacterial strain from root nodules classifying it in the genus Rhizobium (Franche, Lindström and Elmerich, 2009). Although neither nitrogen fixation is limited to Rhizobium spp. nor legumes are the only plants able to take advantage of this process, the legume-rhizobium relation remains the model system to understand plant-microorganism genetic interactions, mutualistic and also parasitic (Den Herder and Parniske, 2009; Franche et al., 2009; Markmann and Parniske, 2009). The legume-rhizobium interaction presents also a unique opportunity to study coevolution (Heat, Burke and Stinchcombe, 2012).

During the classical period of Genetics, peas were probably the plant of choice for plant genetics studies, until both the development of the molecular era and the start of the genomic era transformed the model plant species into the mainstream choice of most cutting-edge research. Arabidopsis thaliana became the plant model par excellence, while Medicago truncatula and Lotus japonicus evolved into the legume model plant species, with Oryza sativa as the monocot example, these are the species for which most of the basic genomic research is performed. Nonetheless, pea somehow remained as a pioneering material. For instance, some pea genes were among the first registered in the National Center for Biotechnology Information (NCBI) database. Interestingly, after the sequencing of the genomes of the model legume species and also the genome of the crop soya bean (Glycine max), the pea genome has not yet been published. The genome sequences of chick pea (Cicer arietinum), common bean (Phaseolus vulgaris) and pigeon-pea (Cajanus cajan) have already been published, what is more, the genomes of other legume species such as lentil (Lens culinaris) are about to be completed (Bett et al., 2014; Jain et al., 2013; Varshney et al., 2012; Varshney et al., 2013).

Returning to the starting point, what do we know in the age of genomics about the genes controlling the characters studied by Mendel? In his work "Versuche über Pflanzen Hybriden"; Mendel described eight characters of which he investigated the segregation of seven. Ever since the beginning of the discipline of Genetics, an enormous curiosity has persisted to know exactly the particular genes that Mendel used in his experiments. During the late twentieth century the questions about what genes, what functions they performed, what mutations originate the recessive alleles, etc., began to be answered. The first character's gene isolated controlled seed shape, with round being dominant over the wrinkled (rugosus) form (Bhattacharyya, Smith, Ellis, Hedley and Martin, 1990). This study demonstrated that the mutation which originated the wrinkled seed shape consisted of a loss-of-function mutation caused by the insertion of a transposon (a mobile genetic element) in a gene encoding a starch branching 
enzyme. The functionality loss of this enzyme produces the wrinkled characteristics of pea seeds. Currently five of these genes have been identified with respect to their function, location, and the mutations that cause the recessive alleles. As shown in Table 1 other known mutations affect one or a few nucleotides generating loss of function alleles (amorphous) or with a decreased function (hipomorfous). There are other candidate genes for characters in the pea genome, nonetheless still no solid evidence exists to say which of the alternative genes Mendel could have used in each particular case. A more complete review of these genes and other aspects of Mendel's work can be found in Ellis et al. (2011) and Reid and Ross (2011).

To sum up, legumes are a key component of terrestrial ecosystems due to their ability to provide nitrogenous nutrients to the soil through the atmospheric nitrogen fixation of their root nodules. They are also essential components of human nutrition as well as to feed domestic animals, in addition having also contributed to the generation of basic and applied knowledge in Biology, particularly in the disciplines of Genetics and Plant Breeding.

Table I. The seven characters of $P$. sativum examined by Mendel and a summary of the genes, phenotypes, presumed functions and mutations involved, together with their location.

\begin{tabular}{|c|c|c|c|c|c|}
\hline Character $^{1}$ & Gene & Function & Mutation & $\begin{array}{l}\text { Linkage } \\
\text { group }\end{array}$ & Reference \\
\hline $\begin{array}{l}\text { Seed shape, round } \\
\text { vs. wrinkled }(R / r)\end{array}$ & Rugosus & $\begin{array}{c}\text { Starch branching } \\
\text { enzyme }\end{array}$ & $\begin{array}{c}\text { Insertion of a } \\
\text { transposable element } \\
(0,8 \mathrm{~kb})\end{array}$ & V & $\begin{array}{c}\text { Bhattacharyya et } \\
\text { al., } 1990 .\end{array}$ \\
\hline
\end{tabular}

\begin{tabular}{|c|c|c|}
\hline $\begin{array}{c}\text { Cotyledn color, } \\
\text { yellow vs. green }(I / i)\end{array}$ & Sgr (staygreen) & $\begin{array}{l}\text { Chorophyll } \\
\text { degradation }\end{array}$ \\
\hline
\end{tabular}

\begin{tabular}{|c|c|c|c|c|c|}
\hline $\begin{array}{c}\text { Stem length, tall vs. } \\
\text { dwarf (Le/le) }\end{array}$ & Le & $\begin{array}{l}\text { Gibberellin-3 } 3 \text { - } \\
\text { hydrolase }\end{array}$ & $\begin{array}{c}\text { Substitution Ala } \rightarrow \\
\operatorname{Thr}(G \rightarrow A)\end{array}$ & III & $\begin{array}{l}\text { Lester et al., } 1997 . \\
\text { Martin et al, } 1997\end{array}$ \\
\hline $\begin{array}{l}\text { Flower color (and } \\
\text { seed coat), purple } \\
\text { vs white }(A / a)\end{array}$ & $b H L H$ & $\begin{array}{l}\text { bHLH transcription } \\
\text { factor }\end{array}$ & $\begin{array}{c}\text { Sustitution G } \rightarrow \text { A } \\
\text { at an exon-intron } \\
\text { border, incorrect } \\
\text { splicing }\end{array}$ & II & Hellens et al., 2010 \\
\hline
\end{tabular}

\begin{tabular}{lc}
\hline & \\
Pod form, inflated & Sclerenchyma \\
vs. constricted & \\
$(V / V)$ or $(P / p)$ & formation in pods
\end{tabular}

III

$(V / v)$ or $(P / p)$

formation in pods

$\mathrm{VI}$

\begin{tabular}{lc}
\hline $\begin{array}{c}\text { Pod color, green vs } \\
\text { yellow }(G p / g p)\end{array}$ & $\begin{array}{c}\text { Chloroplast structure } \\
\text { in pod wall }\end{array}$ \\
\hline
\end{tabular}

Flower position, axial vs. terminal $(\mathrm{Fa} / \mathrm{fa})$ or $($ Fas $/ f a s)$

PsTFL1a?

(DETERMINATE)

Meristem function

Foucher et al., 2003

III

\footnotetext{
${ }^{1}$ Recessive alternatives are underlined.

${ }^{2}$ Both genes, $p$ and $v$, generate similar phenotypes, thus Mendel could have used any of them.
} 
Allen, G. E. (2003). Mendel and modern genetics: the legacy for today. Endeavour, 27, pp. 63-68. http://dx.doi.org/10.1016/ S01609327(03)000656

Anonymous. (1898). Pea-soup as a substitute for beef-tea. Science, 14, p. 264.

Armstead, I., Donnison, I., Aubry, S., Harper, J., Hörtensteiner, S., James, C., Mani, J., Moffet, M., Ougham, H., Roberts, L., Thomas, A., Weeden, N., Thomas, H. and King, I. (2007). Cross-species identification of Mendel's I locus. Science, 315, p. 73. http:// dx.doi.org/10.1126/science.1132912

Bateson, W. (1909). Mendel's Principles of Heredity. New York: Cambridge University Press. Available from: archive.org/stream/ mendelsprinciple00bate\#

Bett, K., Ramsay, L., Sharpe, A. G., Cook, D. R., Penmetsa, R. V., Stonehouse, R., Wong, M., Chan, C. Vandenberg, A., VanDeynze, A., Coyne, C. J., McGee, R., Main, D., Dolezel, J., Edwards, D., Kaur, S., Udupa, S. M and Kumar, S. (2014). Lentil genome sequencing: establishing a comprehensive platform for molecular breeding. En: Book of Abstracts, $7^{\text {th }}$ International Conference on Legume Genetics and Genomics (ICLGG VII), 7-11 July, Saskatoon, Canada, p. 19.

Bhattacharyya, M, K., Smith, A. M., Ellis, T. H. N., Hedley, C. and Martin, C. (1990). The wrinkled-seed character of pea described by Mendel is caused by a transposon-like insertion in a gene encoding starch-branching enzyme. Cell, 60, pp. 115-122. http:// dx.doi.org/10.1016/00928674(90)90721P

Correns, C. (1950). G. Mendel's law concerning the behavior of progeny of varietal hybrids [originally published as: Correns, C. (1900). G. Mendel's Regel über das Verhalten der Nachkommenschaft der Rassenbastarde. Berichte der Deutschen Botanischen Gesellschaft, 18, pp. 158-168]. Genetics, 35, pp. 33-41. Available from: http://www.esp.org/foundations/genetics/classical/holdings/c/cc-00.pdf

Darwin, C. (1876). The Effects of Cross and Self-Fertilization in the Vegetable Kingdom. London: John Murray. Available from: http:// darwin-online.org.uk/converted/published/1881_Worms_ F1357/1876_CrossandSelfFertilisation_F1249/1876_CrossandSelfFertilisation_F1249.html / http://dx.doi.org/10.5962/bhl. title.110800

Den Herder, G. and Parniske, M. (2009). The unbearable naivety of legumes in simbiosis. Current Opinion in Plant Biology, 12, pp. 491-499. http://dx.doi.org/10.1016/j.pbi.2009.05.010

De Vries, H. (1950). Concerning the law of segregation of hybrids [originally published as: De Vries, H. (1900). Sur la loi de disjonction des hybrides. Comptes Rendus de l'Academie des Sciences (Paris), 130, pp. 845-847]. Genetics, 35, pp. 30-32. Available from: http://www.esp.org/foundations/genetics/classical/ holdings/v/hdv-00.pdf

East, E. M. (1910). A Mendelian interpretation of variation that is apparently continuous. American Naturalist, 44, pp. 65-82. http://dx.doi.org/10.1086/279117

East, E. M. (1916). Studies on size inheritance in Nicotiana. Genetics, 1, pp. 164-176.
Ellis, T. H. N, Hofer, J. M. I., Timmerman-Vaughan, G. M., Coyne, C. J. and Hellens, R. P. (2011). Mendel, 150 years on. Trends in Plant Science, 16, pp. 590-596. http://dx.doi.org/10.1016/j. tplants.2011.06.006

Fairbanks, A. J. and Rytting, B. (2001). Mendelian controversies: A botanical and historical review. American Journal of Botany, 88, pp. 737-752. http://dx.doi.org/10.2307/2657027

Fisher, R. A. (1936). Has Mendel's work been rediscovered? Annals of Science, 1, pp. 115-137. http://dx.doi. org/10.1080/00033793600200111

Foucher, F., Morin, J., Courtiade, J., Cadioux, S., Ellis, N., Banfield, M J. and Rameau, C. (2003). DETERMINATE and LATE FLOWERING are two TERMINAL FLOWER1/CENTRORADIALIS homologs that control two distinct phases of flowering initiation and development in pea. The Plant Cell, 15, pp. 2742-2754. http://dx.doi. org/10.1105/tpc.015701

Franche, C., Lindström, K. and Elmerich, C. (2009). Nitrogenfixing bacteria associated with leguminous and non-leguminous plants. Plant and Soil, 321, pp. 35-59. http://dx.doi. org/10.1007/s1110400898338

Franklin, A., Edwards, A. W. F., Fairbanks, D. J., Hartl, D.L. and Seidenfeld, T. (2008). Ending the Mendel-Fisher Controversy. Pittsburgh: University of Pittsburgh Press.

Galton, D. (2009). Did Darwin read Mendel? QJM International Journal of Medicine, 102, pp. 587-589. http://dx.doi.org/10.1093/ qjmed/hcp024

Heath, K. D., Burke, P. V. and Stinchcombe, J. R. (2012). Coevolutionary genetic variation in the legume-rhizobium transcriptome. Molecular Ecology, 21, pp. 4735-4747. http://dx.doi. org/10.1111/j.1365294X.2012.05629.x

Hellens, R. P., Moreau, C., Lin-Wang, K., Schwinn, K. E., Thomson. S. J., Fiers. M. W. E. J., Frew, J., Murray, S. R., Hofer, J. M. I., Jacobs, J. M. E., Davies, K. M., Allan, A. C., Bendahmane, A., Coyne, C. J., Timmerman-Vaughan, G. M. and Ellis, T. H. N. (2010). Identification of Mendel's white flower character. Plos One, 5, e13230. http://dx.doi.org/10.1371/journal.pone. 0013230

Howard, J. C. (2009). Why didn't Darwin discover Mendel's laws? Journal of Biology, 8, p.15. http://dx.doi.org/10.1186/jbiol123

Keeble, F. and Pellew, C. (1910). The mode of inheritance of stature and of time of flowering in peas (Pisum sativum). Journal of Genetics, 1, pp. 47-56. http://dx.doi.org/10.1007/BF02981568

Jahn, I., Lother, R. and Senglaub, K. (1990). Historia de la Biología. Teorías, métodos, instituciones y biografias breves. Barcelona: Labor.

Jain, M., Misra. G., Patel, R. K., Priya, P., Jahwar, S., Kahn, A. W., Shah, N., Singh, V. K., Garg, R., Jeena, G., Yadav, M., Kant, C., Sharma, P., Yadav, G. Bhatia, S., Tyagi, A. K. and Chattopadhyay, D. (2013). A draft genome sequence of the pulse crop chickpea (Cicer arietinum L). The Plant Journal, 74, pp. 715-729. http:// dx.doi.org/10.1111/tpj.12173

Johannsen, W. (1909). Elemente der exakten Erblichkeitslehre. Jena: Fischer. 
Lester, D. R., Ross, J. J., Davies P. J. and Reid, J. B. (1997). Mendel's stem length gene $(L e)$ encodes gibberellin $3 \beta$-hydroxylase. Plant Cell, 9, pp. 1435-1443. http://dx.doi.org/10.2307/3870393 / http://dx.doi.org/10.1105/tpc.9.8.1435

Markmann, K. and Parniske, M. (2009). Evolution of root endosymbiosis with bacteria: how novel are nodules? Trends in Plant Science, 14, pp. 77-86. http://dx.doi.org/10.1016/j. tplants.2008.11.009

Martin, D. N., Proebsting, W. M. and Hedden, P. (1997). Mendel's dwarfing gene: cDNAs from the Le alleles and function of the expressed proteins. Proceedings of the National Academy of Sciences USA, 94, pp. 8907-8911. http://dx.doi.org/10.1073/ pnas.94.16.8907

Mayr, E. (1982). The Growth of Biological Thought. Diversity, EvoIution, and Inheritance. Cambridge, Massachusetts: Belknap Press-Harvard University Press.

Mendel G. (1866). Versuche über Pflanzen-Hybriden. Verhandlungen des Naturforschenden Vereines in Brünn, IV, pp. 67-112. http://dx.doi.org/10.5962/bhl.title.61004

Nilsson-Ehle, H. (1908). Einige Ergebnisse von Kreuzungen bei Hafer und Weizen. Botaniska Notiser, 6, pp. 257-294.

Nilsson-Ehle, H. (1911). Mendélisme et acclimatation. En: IV Conférence International Génétique, Paris, pp. 1-22.

Osborne, T. B. and Harris, I. F. (1907). The proteins of the pea (Pisum sativum). Journal of Biological Chemistry, 3, pp. 213-217.

Osborne, T. B. and Heyl, F. W. (1908a). Hydrolysis of vicilin from the pea (Pisum satibum) (sic). Journal of Biological Chemistry, 5, pp. 187-195.

Osborne, T. B. and Heyl, F. W. (1908b). Hydrolysis of legumelin from the pea (Pisum satibum) (sic). Journal of Biological Chemistry, 5, pp. 197-205.

Reid, J. B. and Ross, J. J. (2011). Mendel's genes: Toward a full molecular characterization. Genetics, 189, pp. 3-10. http://dx.doi. org/10.1534/genetics.111.132118

Roberts, H. F. (1919) The contribution of Carl Friedrich von Gartner to the history of plant hybridization. The American Naturalist, 53, pp. 431-445. http://dx.doi.org/10.1086/279723

Roberts, H. F. (1929). Plant Hybridization before Mendel. New York: Princeton University Press. http://dx.doi.org/10.5962/bhl. title. 4517
Sax, K. (1923). The association of size differences with seed-coat pattern and pigmentation in Phaseolus vulgaris. Genetics, 8, pp. 552-560.

Smykal, P. (2014). Pea (Pisum sativum L.) in Biology prior and after Mendel's discovery. Czech Journal of Genetic and Breeding, 50, pp. 52-64.

Stern, C. and Sherwood, E. R. (1966). The Origin of Genetics. San Francisco: Freeman [Spanish translation: El origen de la Genética. Madrid: Alhambra, 1973].

Tschermak, E. (1950). Concerning artificial crossing in Pisum sativum [originally published as: Tschermak, E. (1900). Über Künstliche Kreuzung bei Pisum sativum. Berichte der Deutsche Botanischen Gesellschaft 18, pp. 232-239]. Genetics, 35, pp. 42-47 (1950). Available from: http://www.esp.org/foundations/genetics/classical/holdings/t/et-00.pdf

Varshney, R. K., Song, C., Saxena, R. K., Azam, S., Yu, S., Sharpe, A. G., Cannon, S., Baek, J., Rose, B. D., Tar’an, B., Millan, T., Zhang, X., Ramsay, L. D., Iwata, A., Wang, Y., Nelson, W., Farmer, A. D., Gaur, P. M., Soderlung, C., Penmetsa, R. V., Xu, C., Bharti, A. K., He, W. Winter, P. Zhao, S. et al. (2013). Draft genome sequence of chickpea (Cicer arietinum) provides a resource for trait improvement. Nature Biotechnology, 31, pp. 240-246. http:// dx.doi.org/10.1038/nbt.2491

Varshney, R. K., Chen, W., Li, Y., Bharti, A. K., Saxena, R. K., Schlueter, J. A., Donoghue, M. T. A., Azam, S., Fan, G., Whaley, A. M., Farmer, A. D., Sheridan, J., Iwata, A., Tuteja, R., Penmetsa, R. V., Wu, W., Upadhyaya H. D., Yang, S.-P., Shah, T., Saxena, K. B., Michael, T., McCombie, W. R., Yang, B., Zhang, G., Yang, H. et al. (2012) Draft genome sequence of pigeon pea (Cajanus cajan), an orphan legume crop of resource-poor farmers. Nature Biotechnology, 30, pp. 83-89. http://dx.doi.org/10.1038/nbt.2022

Vavilov, N. I. (1922). The law of homologous series in variation. Journal of Genetics, 12, pp. 47-78. http://dx.doi.org/10.1007/ BF02983073

Weldon, W. F. R. (1902). Mendel's laws of alternative inheritance in peas. Biometrika, 1, pp. 228-254. Available from: http://www. esp.org/foundations/genetics/classical/holdings/w/wfrw-02. pdf / http://dx.doi.org/10.1093/biomet/1.2.228 